\title{
PLANT ECOLOGY OF THE NAMIB DESERT
}

\section{Patrick VAN DAMME}

Faculty of Agricultural Sciences

Coupure Links 653

$B$ 9000 Gent

Belgium

CURRENT RESEARCH INTEREST: tropical and subtropical ethnobotany, salt and drought stress of crops.

\section{SUMMARY}

The Namib desert is reportedly the oldest desert in the world. It consists of a number of very distinct ecosystems, six of which are dealt with in this text. Among them are the sand dune, the dry river bed and the domed inselbergs vegetation. The importance of fog water absorption for the Namib flora is discussed. Two important and noteworthy endemic plant species, i.e. Welwitschia mirabilis and Acanthosicyos horrida are treated extensively, because of their great interest for plant physiology and ethnobotany, resp. Special attention is given to the importance of the CAM photosynthetic system for Namib desert plant survival. Where possible the ethnobotanic importance of the species is discussed.

KEY WORDS: Acanthosicyos horrida, desert flora, drought stress, ethnobotany, succulents, Welwitschia mirabilis

\section{Introduction}

Approximately half of Africa's surface area can be classified as extremely arid, arid or semi-arid. One quarter to one third of the continent's surface is occupied 
by the world's largest desert - the Sahara - which extends over $4800 \mathrm{~km}$ from the Atlantic to the Red Sea with a maximum width of almost $2000 \mathrm{~km}$.

The Namib desert forms the second largest zone of extreme aridity. To the east of it lies the world's largest continuous expanse of sand - the Kalahari region. These reddish sands, however, are now fixed by vegetation and the dune form is now a rarity.

At first sight, vegetation and animal life seem to be almost completely absent from the Namib desert. A closer look, however, shows there is a lot going on in the area. Especially at night, the desert comes to life and a lot of insects, snakes and geckoes become active. Especially in the rocky part of the desert and in and around the semi-permanent rivers there are a great number of plants that are able to withstand the harsh desert conditions or have developed ways to survive during the short periods that the climatic conditions are optimal for plant growth.

The Namib desert flora has recently attracted more interest because it is now known to be a reservoir of interesting plant species that form a germplas that can be used in breeding for new drought tolerant species and varieties. The International Board for Plant Genetic Resources, which is based in Rome, regularly organizes plant collection trips to establish a collection of these plants.

The author of the present article is currently monitoring a research project sponsored by the European Community studying the floral diversity of the Namib desert with particular emphasis on the ethnobotanical importance, i.e. the potential uses by man, of the plant species that are identified under the project. This article reviews the current knowledge of the Namib flora and its ethnobotanical properties.

\section{Geographical Demarcation and Topography (Walter, 1986)}

The Namib lies on the western coast of southern Africa. It stretches from the San Nicolai River (14 $20^{\prime} \mathrm{S}$ ) in southern Angola to the Olifants River (about $32^{\circ} \mathrm{S}$ ) in southern Namibia over a length of almost $2000 \mathrm{~km}$. This does not include the area south of the Orange River which is called Namaqualand. The latter mainly receives winter rains tied to cyclones, whereas the Namib has a summer rain regime. 
The Namib desert forms a strip 80 to $150 \mathrm{~km}$ broad from the Atlantic coast rising to the east with a $1 \%$ gradient to about $1000 \mathrm{~m}$ (the Great Western Escarpment).

- From north to south three sections can be distinguished:

(1) the northern Namib stretching between the northern boundary and the Unjab or Ugab River; to most visitors this part more resembles a savannah than a desert;

(2) the central Namib from the Unjab to the Kuiseb River;

(3) the southern Namib to the Orange River.

- Going from west to east, the central Namib can also be subdivided into three parts:

(1) a narrow coastal strip;

(2) the outer Namib, which is about $50 \mathrm{~km}$ wide with only episodic rainfall;

(3) the inner Namib with an annual precipitation of 50 to $100 \mathrm{~mm}$ of summer rain.

The relief of the central Namib is not well developed, i.e. there are hardly any differences in height caused by erosion, and therefore Logan (1960) describes this as the Namib peneplain or platform. This platform mainly consists of truncated bedrock of various types and ages. Scattered, isolated mountains rise steeply and abruptly above the platform, and in the northern half, streams have carved deep, steep-walled gorges. In much of the southern half of the desert the platform is surmounted by a vast expanse of sand.

The present review will especially focus on the Kuiseb River's and the central Namib's ecology and floristic composition. The Kuiseb is inhabited by a number of small communities of Topnaar (in the literature these people are also named Topnaar Nama, Khoikhoin, or Hottentots) who have adapted to its harsh conditions. They have also learned how to use some of the special plants occurring in this biotope.

A large part of the coastal dunes is taken by private diamond mining companies which prevent any thorough floristic research, whereas the southern Namib mainly consists of sand dunes without any important vegetation. For a good, in depth introduction to the Namib desert's overall characteristics the reader is referred to Walter (1986) which is a major source on the subject. 


\section{Climate, Soils and Hydrology}

\subsection{General Climatic Conditions}

The Namib is tributary to its position on a west coast near a cold ocean current, the Benguela Current, with water temperatures of about $10^{\circ} \mathrm{C}$. This temperature is too cold to allow much evaporation, therefore the prevailing winds blowing into the land from the west do not give rise to rains. The result is an extremely dry and rainless desert with, however, a high relative air humidity caused by heavy wet fogs that occur regularly.

Fluctuations in temperatures are small. There are only a few days with high temperatures and there is no frost or hail. This is due to a permanent temperature inversion: a cold layer of air up to $600 \mathrm{~m}$ high lies over the cold Benguela current and the land adjacent to it. This air layer effectively blocks the warm air currents from coming overland from the east. The predominant winds come from the sea bringing somewhat cooler, humid air (Walter, 1986).

Temperature and evaporation values differ according to the weather station's location. Logan (1969) gives detailed data. The main temperature characteristic is the small fluctuations throughout the year: the mean difference between the hottest and coldest month is about $6^{\circ} \mathrm{C}$. Potential evaporation can be as high as $3500 \mathrm{~mm}$ $\mathrm{yr}^{-1}$, especially in more inland locations. Evaporation on a daily basis balances between high values on days with southwestern winds (dry, hot and dusty) and low values on foggy days.

Precipitation is unevenly distributed over subsequent years. 'Extreme' rainy years, with rain heights of over $100 \mathrm{~mm}$, are known to occur only rarely. Basically, years with more than $20 \mathrm{~mm}$ of rain occur rarely. In the coastal and outer Namib, most rains fall in summertime. This intensifies aridity (Seely and Stuart, 1976). These rains come from the east, from the Indian Ocean, and only occur when there is no temperature inversion and no sea breeze (which, coming from the west, would hold off western winds). They usually occur as short-lived torrential thunderstorms. On rare occasions, snow falls on the higher southern mountains and freezing temperatures are recorded along the inner edge of the desert.

\subsection{The Live-bringing Fog}

Rains, however, are not the most important source of humidity for the Namib's ecology. Fog and dew are of much greater importance. They are related to the fog 
bank which almost permanently overlies the Benguela Current. The sea breeze carries the fog from the sea towards the land where it moves above the soil surface. At night, colder temperatures induce condensation of the humidity laden sea breeze. The fog is dissolved during the day as the soil is heated up by radiation penetrating through the fog.

This type of fog must be differentiated from the ground fog occurring inland which is created at soil level during the night from the loss in temperature with radiation. The borderlines between the dry eastern and the humid western air masses continuously move back and forth in both directions resulting in rapid changes in temperature and humidity.

Fog moving inland is easily caught by, especially vertical, obstacles. As Walter (1986) so neatly states, the highest amounts of water from fog are obtained when the obstacle has a large surface and transmits wind at the same time.

\subsubsection{Fog and Plants}

Crowns of trees are a typical example whereby moisture is trapped and turned into water.

A number of plants can immediately take up this water through their above ground parts.

A good example is Trianthema hereroensis (Aizoaceae) which is a common succulent found in the coastal dunes. This plant rapidly absorbs fog water through its leaves, apparently to supplement the water obtained through its roots from moisture stored in the sand. It only grows as far inland as the fog regularly penetrates. As a result of this relatively dependable water supply it flowers and produces seeds throughout the year and is thus an important source of food and shelter for many dune animals (Seely, 1987).

The most common large grass of the dunes, Stipagrostis sabulicola, also uses fog water which it absorbs through its extensive network of roots which lie just below the sand surface. This grass occurs throughout the dune sea, possibly obtaining moisture from dew in the east where fog occurs infrequently. S. sabulicola also flowers and produces seeds throughout the year, even during the dry season. On the plains, the characteristic Namib desert dwarf shrub Arthraerua leubnitziae (Amaranthaceae) may also use fog water, albeit in an indirect way (cf. infra). 
Rocks also collect water in this way. Through gravity the water can collect in fissures where it can sustain ephemeric or longer-lived vegetation.

\subsubsection{Fog and Animals}

A number of insects have developed specific ways to trap water and thus survive in this otherwise hot and dry environment: Onymacris unguicularis, the 'fogbasking' beetles, adopt a vertically inclined position, called head standing, to trap water. They turn their body so that it faces into the wind, straighten out their rear legs and lower their heads. The backs of the beetles thus serve as condensation surface for the fog where it forms into droplets of water which glide downward. The beetles can drink the water which hangs in drops from their mouth parts (Seely, 1987).

\subsection{Hydrology}

Owing to the lack of precipitation, the Namib has a poorly developed and fragmentary drainage system. In the desert's northern half the larger streams reach the sea, but between the Kuiseb and the Orange rivers, every stream terminates in a vlei (salt pan or mud flat) against or among the dunes.

The Namib is crossed by a small number of semi-permanent rivers (photo 1). Locally, they are designated by their Afrikaner name of riviere (the plural of rivier, meaning a river which carries water only intermittently; this term is herewith equivalent to wadi and oued which are used in other countries). Water falling inland is collected on the high plateau from which these riviere originate. Water only reaches the sea after heavy rainfall. If the rains are not heavy enough the waters drain off into the river beds without ever reaching the coast.

The Kuiseb river (photo 2) forms the borderline between the sandy, southern part of the Namib and the stony, mostly granitic, northern part. It depends on these regular gushes of water to carry away the sand blown into its bed in between two subsequent floods.

\subsection{Soils}

Large areas of the Namib are completely soilless, with bedrock at the surface. Arable soils are limited to the floodplains and terraces of major rivers. The base rocks are Precambrian metamorphites such as micaschists, quartzites and marbles. 


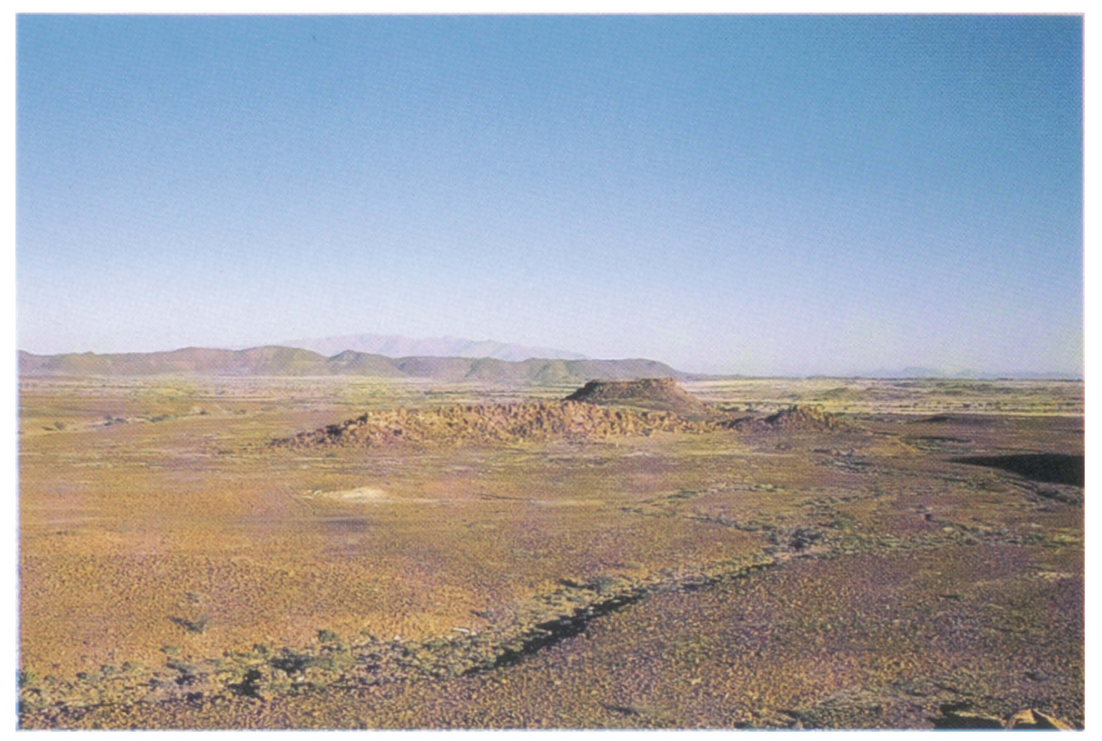

1

Downloaded from Brill.comఠ4/26/2023 12:55:25PM

via free access 
photo 1: A small semi-permanent river in the stony northern part of the Namib. These riviere, as they are called in Afrikaans, enable some perennial plants to survive in the middle of the desert. It is the typical habitat of the endemic Welwitschia mirabilis 
photo 2: In larger riviere as the Kuiseb a permanent and shallow water table provides enough moisture to maintain a more luxuriant vegetation. Acacia erioloba is one of the main components of this biotope 


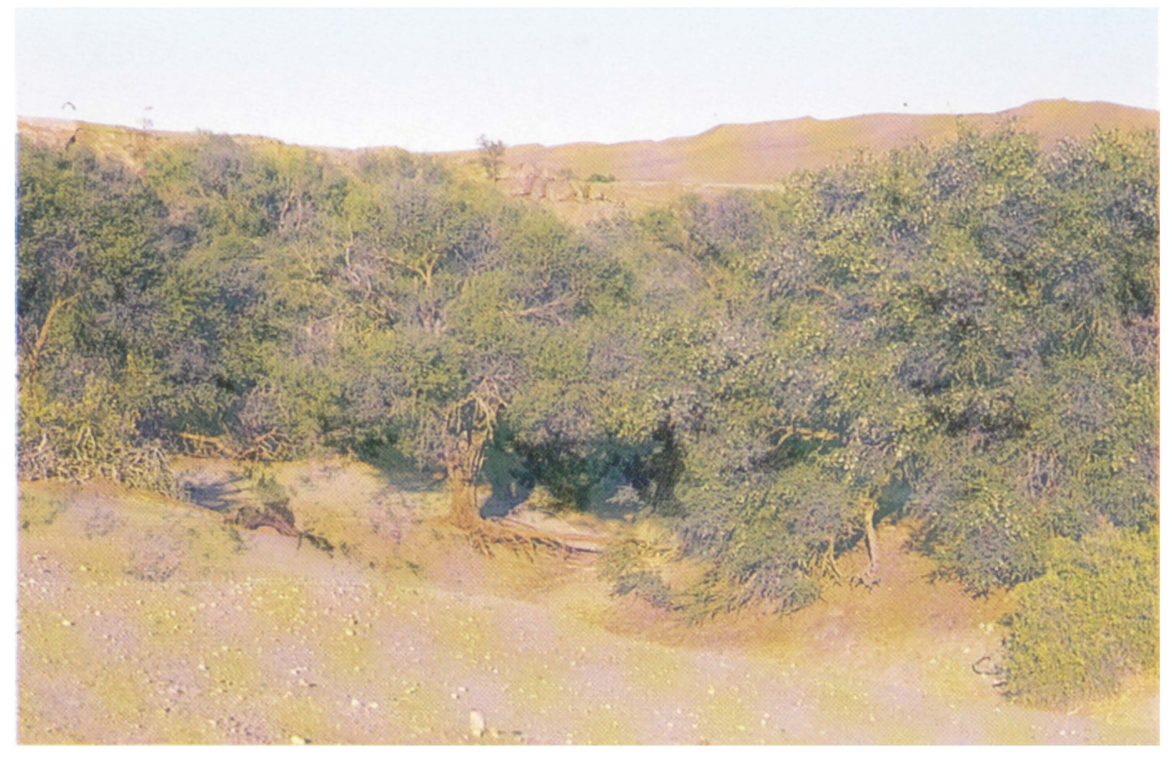




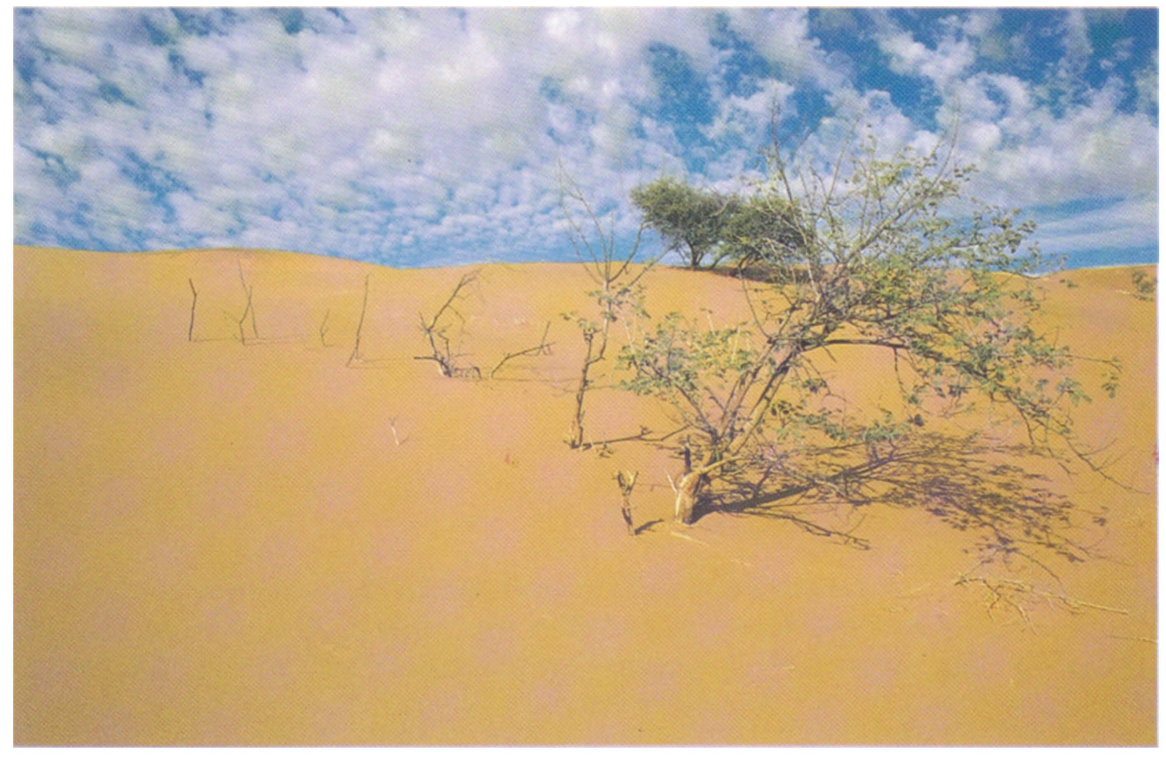


photo 3: Large parts of the Namib are covered with sand dunes. The reddish sand contains lots of mica particles, which reflect the sunlight. This profound rooting Acacia-tree only survives by the grace of a nearby river bed 
photo 4: One of the halophytic inhabitants of the river beds is this showy flowering Mesembryanthemum guericheanum. This plant changes its photosynthesis metabolism $\left(C_{3}-C A M\right)$ according to the available moisture 


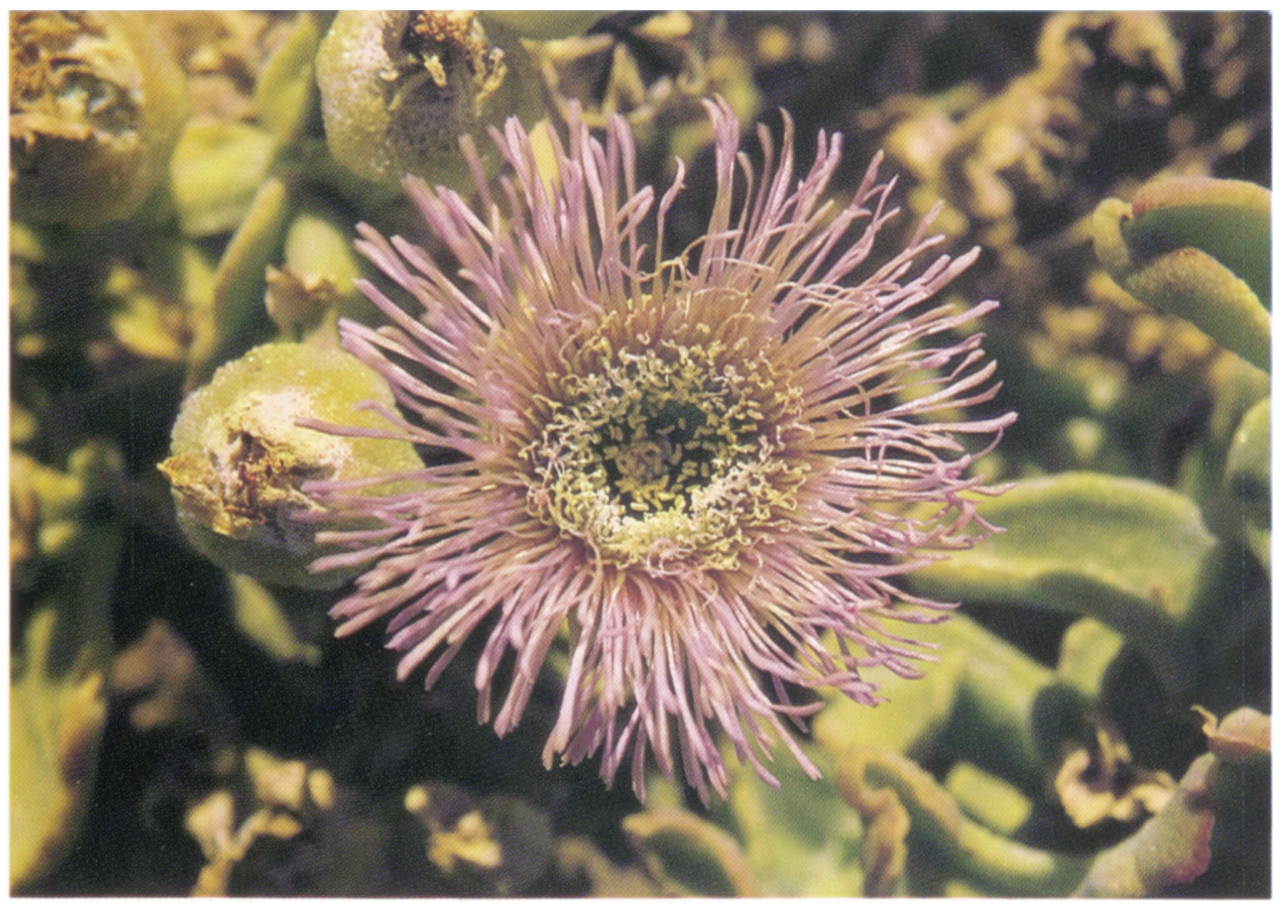




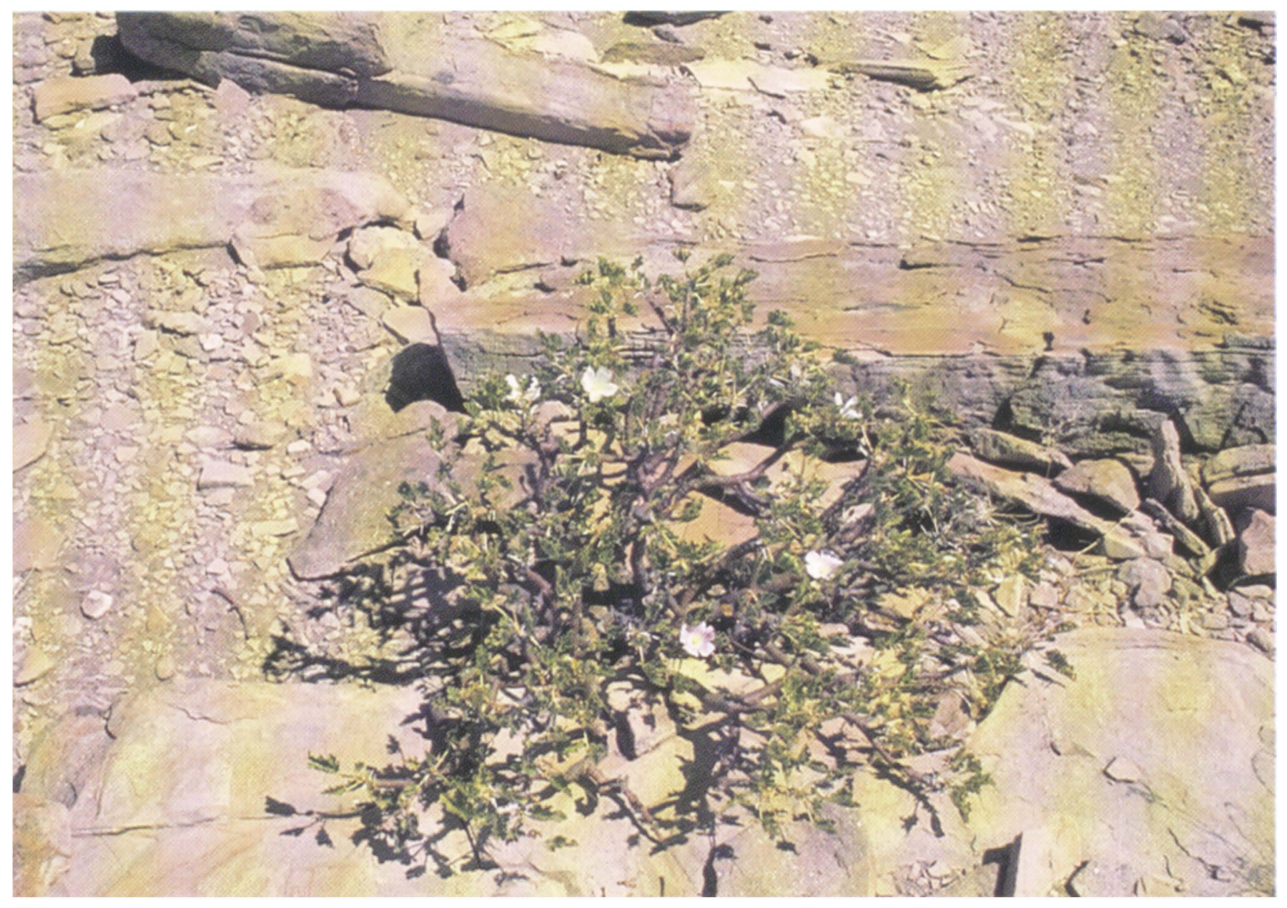


photo 5: Sarcocaulon marlothii is locally called bushman's candle. Once the inner part of the stem has withered, only the waxy bark remains, which can be lighted as a candle. 
photo 6: Euphorbia damarana is one of the large stem succulent Euphorbias of the Namib. It is easily recognized by its large yellow fruits and because it forms thick bushes of pencillike stems 


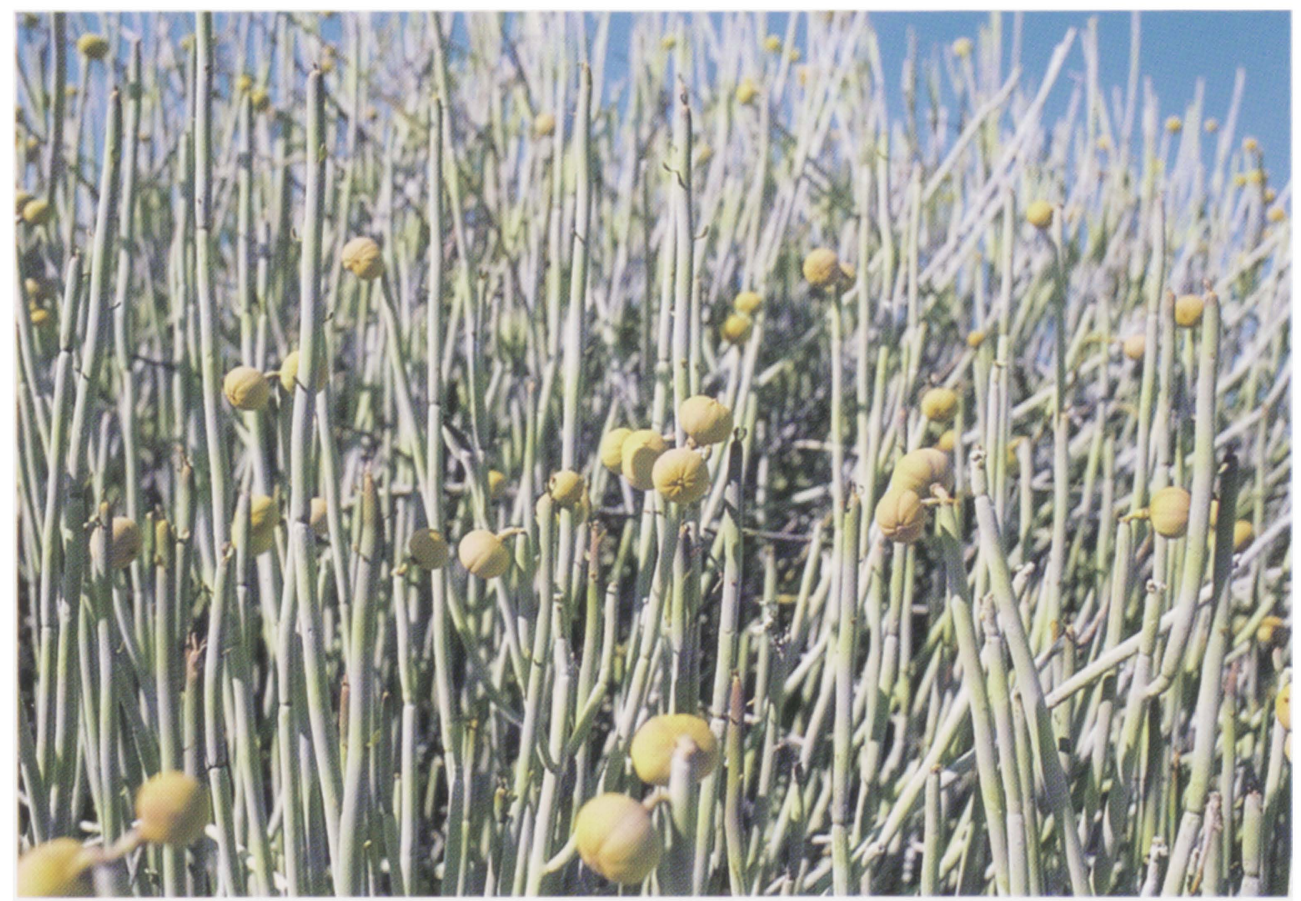




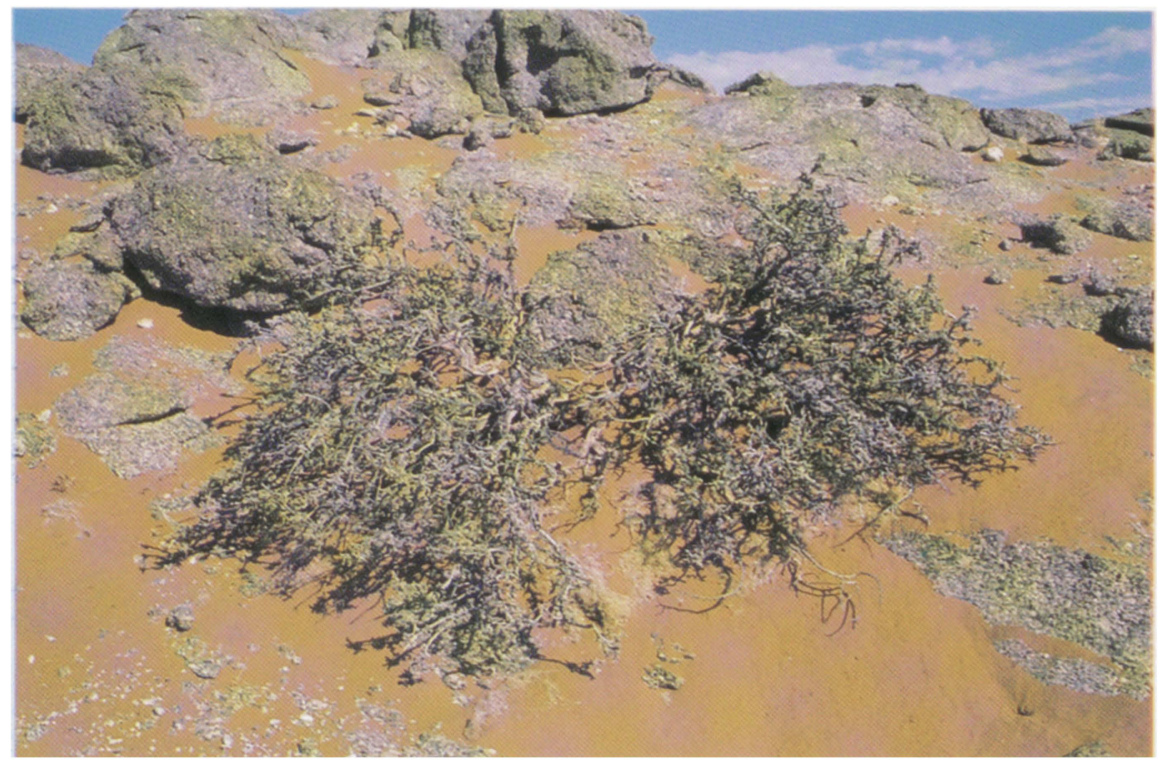


photo 7: A Salsola-shrub apparently dry and dead. When rains will come, however, the plant will produce small scale-like leaves. Plants which survive dry periods in a completly dessicated state are called resurrection plants 
photo 8: Welwitschia mirabilis is a curiosity both in its appearance and in a botanical context. It produces only two leaves, which continue to grow during the whole life of the plant. The leaves of this male specimen, several hundreds of years old, die off at the tip and have been split lenghtwise. As a result the plant seems to consist of a cluster of numerous leaves

photo 9: $W$. mirabilis is dioecious. These are the microsporangiate strobili of a male plant

photo 10: The ovulate strobili are somewhat bigger than the male ones. Each scale of the cone covers one seed, but not every seed is viable due to an always present Aspergillus niger infection. The resemblance with the cones of pines indicates the relationship with other Gymnosperms 

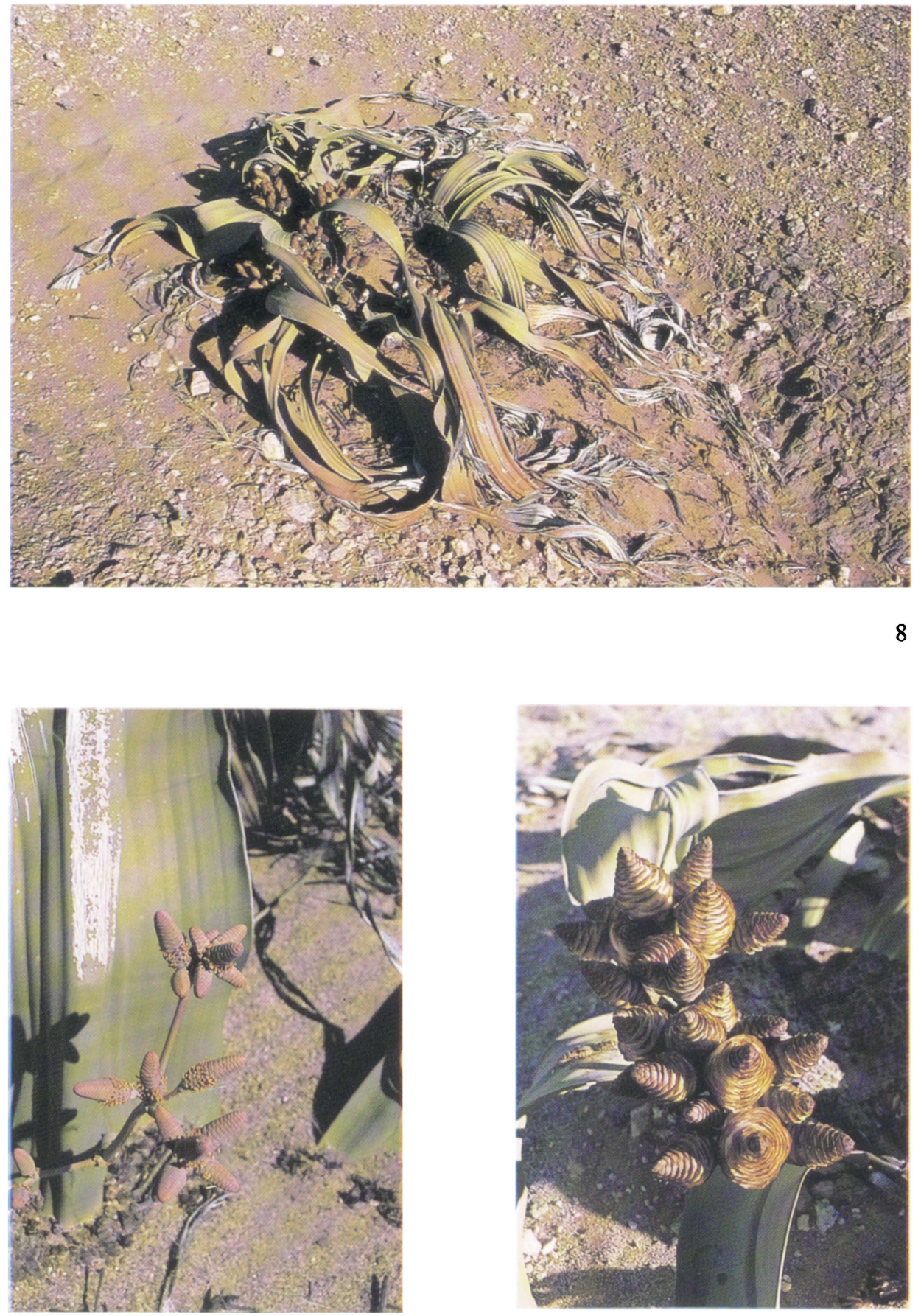
The micaschists have partly been metamorphosed into granite (Martin, 1965). Mesozoic granites form some of the most important mountain complexes. For soil formation, however, Tertiary crusts covering the whole area are more important.

The Namib is something of an open-air museum for geologists. In a number of places, Carbon coal layers 200 million years old, are surfacing. Through weathering and subsequent wind erosion petrified forests bear witness of an ancient more luxuriant vegetation.

Physical weathering of rocks is important as it is in all deserts (Besler, 1972). High surface temperature differences have a devastating effect on rock formations. In the Namib, fogs add an important chemical weathering factor. Saline fog water decomposes rocks especially in shady locations if and where water does not evaporate too quickly (shade weathering: Knetsch, 1960).

The sand desert part covers an area of $34000 \mathrm{~km}^{2}$ and extends over $300 \mathrm{~km}$ along the Atlantic coast (between Luderitz, $26^{\circ} \mathrm{S}$ and the Kuiseb river, $23{ }^{\circ} \mathrm{S}$ ) and for $100-150 \mathrm{~km}$ inland. The sand sea is dominated by large linear dunes, with individual dunes having lengths of 15 to $30 \mathrm{~km}$ and reaching heights of 60 to 240 $\mathrm{m}$. The troughs between them are interrupted by smaller, transverse dunes. There are areas of star and reversing dunes on its eastern margins and a belt of simple and compound transverse and barchanoid dunes along the coast. Sands from the Namib sand desert generally have medium to fine texture. Coarser sands occur in southern areas of the sand sea, and in interdune areas; finer sands in the crestal areas of linear and star dunes (Lancaster \& Ollier, 1983).

The sand could be a weathering product from the underlying sandstone formation (called Tsondab or Namib Sandstone by Besler \& Marker (1979), or Stormberg Sandstone), or accumulated overtime through fluvial processes (this is a similar hypothesis as for the Sahara) after weathering of the Great Escarpment lying to the West (Besler, 1980). Large areas of sand in the coastal regions of the Namib originate from former extensive beach deposits which were exposed when sea levels got lower.

The Namib is a typical 'shining' desert: lots of small mica fragments reflect the sunlight.

Soils are developed on rock debris as well as on erg sands. They both rarely carry any vegetation. Slightly eroded surfaces carry soils with calcareous crusts especially in the eastern inland part of the Namib. Towards the coast the crust contains more gypsum mixed with calcium carbonate. Closer to the coast they 
become salty. The ontogenic processes, i.e. the origin and development history, of these crusts is not fully understood (for more details about theories, see Martin, 1964).

\section{The Namib Fauna}

Although out of the scope of this article, we will briefly give an idea about the fauna inhabiting the Namib desert.

Animal life varies with the vegetational regions of the desert. Generally, dwarf elephant, rhinoceros, antelope, ostrich and zebra are found on the plains and dunes of the Inner Namib, insects and reptiles on the barren outer Namib, and large flocks of marine birds and a few jackals along the coast. The semi-permanent rivers support fish and even waterturtles (Pelomedusa subrufa; Dumont, 1987).

\section{Floral History}

Mainly because of the great diversity of sand-dwelling adaptations, the Namib is regarded by most researchers as the oldest desert in the world.

Current thinking concludes that the climate of the narrow coastal tract between the southern Atlantic Ocean and the Great Western Escarpment (the present-day Namib desert) has fluctuated between arid and semi-arid for at least the last 80 million years. This does not mean that the dunes are that old or that any of the other features we see today looked the same that long ago. The landscape has been changing continually and has been modelled under the influence of episodic rainfall or water flowing into the desert from further inland (Seely, 1987).

Geologist studying rock formations estimate deserts to be about 60 million years old which takes them back to early Tertiary times. Paleobotanists, on the other hand, looking at fossil-plants, estimate that deserts go back no further than late Cenozoic times (i.e. one to five million years). All desert-adapted plants and animals are believed to have evolved within this brief time.

The Mesozoic era (135 - 205 million years ago) is often called the age of the gymnosperms; it preceded the Cenozoic era, also known as the age of the 
angiosperms. It seems therefore quite probable that Welwitschia mirabilis (photo 8, 9 and 10), a plant that only occurs in the Namib desert (see infra) and which taxonomically is situated between the gymnosperms and angiosperms, existed before the onset of desert development.

Although $\mathbf{W}$. mirabilis is perhaps the most typical Namib desert plant one should keep in mind that botanically speaking it shares a number of structural and reproductive features with the jungle (thus humid conditions !) genus, Gnetum. Moreover, it has few true xeromorphic features and it was probably the first plant to have developed CAM photosynthesis (see infra). All these characteristics might well indicate that the Namib once had a wet and humid climate. It is also possible that this plant was the only one to adapt successfully and over time to the increasing aridity which ultimately culminated in so extreme a desert. If so, perhaps the Namib is not quite as old as is usually claimed (Bornman, 1978).

\section{Vegetation of Different Land Forms, Floristic Composition and Ethnobotanical Notes}

Giess (1981) has published a detailed outline of the Namib flora, including records of some seventy vegetation stands and an extensive list of plant species by family. Jacobsen \& Moss (1987) collected and observed 207 different species in the northern Namib. Currently Craven (unpublished data; 499 species inventoried) is undertaking a similar - even more ambitious - work which will also involve ethnobotanical appreciations of the different species described.

In what follows, the following biotopes will be treated (the classification partly follows Walter (1986)):

- the outer Namib with

(1) the oasis-like vegetation of the large riviere which originate on the high plateau, whereby the Kuiseb case will be discussed extensively;

(2) the sand dunes with only sporadic vegetation;

(3) the rocky ridges with their crevices; 
(4) the rock debris covered peneplains (which will not be discussed extensively here: they are only inhabited by a number of lichens (Doidge, 1946; Mattick, 1970); occasionally after a rain, halophytic species (i.e. plants that partly depend

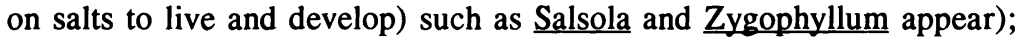

- the inner Namib carries

(5) grasslands;

(6) typical Welwitschia biotopes in small riviere;

(7) domed inselbergs (bornhardts).

On its fringes the true Namib desert gradually "peters out": with the somewhat increasing humidity and rainfall, the vegetation gradually becomes more luxurious. Especially along semi-permanent rivers a sparse type of gallery forest builds up.

Like in every desert, the Namib also has its omnipresent species. In North American deserts, it is the creosote bush and this same plant, surprisingly, is common also in the Argentine's Patagonian desert. In the Namib, the most striking species in this respect is the ever-flowering Arthraerua leubnitziae with its tiny fluted stems (the pencil plant; Amaranthaceae). Quite common too is the succulent-leaved Zygophyllum stapfii.

We are aware of the fact that this is only a general introduction to the variety of plant associations occurring in the Namib. An in depth treatment would fall outside the scope of this article, however.

\subsection{Riviere Vegetation: the Kuiseb Case}

The riviere collect the waters from the upland plateau. Depending on the amount of water collected, the water flows towards the sea or seeps into the sandy river beds. Water seepage results in a permanently high water table under the river beds and in the narrow river valley around it. This water table enables a specific oasislike vegetation to thrive.

Whenever a flood passes, most of the vegetation is destroyed, with the notable exception of deep-rooted and well-established perennial trees such as:

Acacia albida (syn. Faidherbia albida) and Acacia erioloba (both Leguminosae), Euclea pseudebenus (Ebenaceae), Salvadora persica (Salvadoraceae), Ziziphus mucronata (Rhamnaceae) and Tamarix usneoides (Tamaricaceae) (photo 2). 
Due to the permanent groundwater source, Acacia albida does not show the seasonality it does in truly Sahelian settings where it sheds its leaves during the rainy season and develops new leaves during the dry season. This lack of seasonality has also been reported in similarly permanently watered settings (e.g. southern Sudan). Barnes (personal communication) suggests there are substantial differences in leaf production phenology between provenances. A. erioloba (the camel thorn or thorntree) is the other dominant tree species in the Kuiseb ecosystem. Both acacias produce palatable pods which are eaten by goats and sheep. The camel thorn seeds can be (and are) used as a coffee substitute (Watt \& Breyer-Brandwijk, 1962).

The edible fruits of Euclea pseudebenus (the ebony tree;) are less palatable due to their bitter-sweet flavour. Its wood can be used for furniture. The real mustard tree, Salvadora persica, yields fruits that are juicy, but thirst-provoking when consumed. They have a rather pleasant taste. The fruits of Ziziphus mucronata are considered to be a famine food; they are harvested during the tiding over period. Tamarix usneoides is an indicator of more saline stands. Locally, there is no specific use for it.

Two fig species, Ficus sycomorus and F. cordata, can also be found in the riverine forests. They provide fruit throughout the year as they flower and fruit at several times. Baboons and birds feast on them. Striped field mice eat figs which have fallen on the ground (Seely, 1987).

F. sycomorus (the common cluster fig or sycamore fig) is one of the most striking trees of southern Africa. It is also one of the most widely distributed tree species on the continent. The large, buttressed, yellowish trunks are often a prominent feature along rivers and streams, in swampland and savannah. The figs are usually densely clustered on the main branches. They often fall off before ripening and mature on the ground.

Other trees found in riviere include Azima spinosissima (Salvadoraceae), Rhus populifolia (Anacardiaceae) a bush-tree with evergreen, sclerophyllous (i.e. well-protected against water loss) leaves, usually growing on the edges of dry river beds) and Adenolobus gariepina (Leguminosae).

All the species that have been discussed up to this point, are not specific for the Namib area. A number of them (e.g. Ficus sycomorus and Acacia albida) even have a wide distribution over the continent and beyond. 
A notorious, even obnoxious immigrant, is Nicotiana glauca (Solanaceae) which originally comes from America. It disperses easily through its abundant seeds. Together with Ricinus communis (Euphorbiaceae; originally coming from East Africa and India) it develops into small trees which are easily washed away with a good flood. Solanum incanum (Solanaceae), a shrub with hairy leaves grows in dry rivers but also on the slopes. Monechma mollissimum (Acanthaceae) also has hairy leaves and is mostly found on the banks of dry river beds.

Amongst the less conspicuous plants, there are a number of Papaveraceae (Argemone mexicana), Solanaceae (Datura innoxia), Leguminosae (Psoralea obtusifolia), Zygophyllaceae (Tribulus zeiheri and Zygophyllum longicapsulare, a semi-prostrate small shrub with slightly succulent leaves, growing in the vicinity of or in dry river beds), Hydrophyllaceae (Codon royenii, a spiny herbaceous plant only growing in river beds) and many Poaceae.

Immigrant species are also noteworthy here. Most of the species found here can also be encountered in the rest of Namibia (Von Willert et al., 1984). Boyer \& Boyer (1989) have made a thorough survey of the alien, invasive plants of the major rivers of the Namib desert. It would seem that the Kuiseb and Swakop rivers have the densest infestations. Datura innoxia and Nicotiana glauca (both Solanaceae) are the most abundant species. D. innoxia is something of an ephemeral species (see 7.2.) and therefore rather difficult to eradicate but does not negatively influence the indigenous vegetation. $\mathbf{N}$. glauca, Prosopis spp. (mesquite; Leguminosae) and Ricinus communis (Euphorbiaceae) are perennials and appear to have a greater impact on the local vegetation. Whenever possible their further spread should be prevented.

The Poaceae are well represented across Namibia and in the Namib desert itself (for an extensive descriptive list: Müller, 1985). A number of them especially colonize dry riviere beds and can thus also be found in the Kuiseb: Cladoraphis spinosa (syn. Eragrostis spinosa), Cynodon dactylon, Eragrostis rotifer, Hyparrhenia hirta, Setaria appendiculata, Sorghum verticilliflorum, Stipagrostis namaquensis are amongst the most representative examples. Echinochloa holubii only grows in places that are regularly flooded. When this occurs it can build dense stands. Dichanthium papillosum and Chloris virgata grow on heavy soils where water accumulates. Setaria finita colonizes shadowy stands on the rivers' banks. Several species are eaten by cattle. Some have medicinal or even poisonous properties (e.g. Cynodon dactylon and Sorghum verticilliflorum yield hydrocyanic acid; Watt \& Breyer-Brandwijk, 1962).

Basically, the ground water of the Kuiseb is non-saline. Near the coast and on occasion also further inland, however, salt-laden fog sprays can deposit considerable quantities of salt on the soil (Boss, 1941 and Walter, 1936, both cited by Walter (1986) give figures of up to $\left.20 \mathrm{~g} \cdot \mathrm{m}^{-2} \cdot \mathrm{yr}^{-1}\right)$. After a heavy rain, the many side-riviere concentrate this salt into the larger ones. If subsequent evaporation is considerable, the conductivity of the remaining water or soil solution can be rather high (meaning that the water contains a lot of salt and is thus not suited for plant growth). Salt can also form superficial crusts. It should be noted that these higher 
conductivity soils often occur in spots so that halophilous and non-halophilous species can grow in the riviere close to one another.

Typical halophytes are growing in or near the river bed and in the riviere's estuaries. Walter (1986) mentions Arthrocnemum affine, Atriplex vestita and Suaeda plumosa (all three Chenopodiaceae, a typical halophytic family), Heliotropium curassavicum (Boraginaceae), Juncus arabicus (Juncaceae), Mesembryanthemum guericheanum (photo 4) and Psilocaulon salicornioides (both Aizoaceae), Odyssea paucinervis (a sometimes with salt crystals covered Poaceae), Tamarix usneoides and Zygophyllum simplex (Zygophyllaceae).

\subsection{The Dunes}

\subsubsection{Grasses}

The vegetation of the dunes near the river bed includes a number of grasses: Stipagrostis lutescens, $\mathbf{S}$. namaquensis, $\mathbf{S}$. sabulicola and Centropodia glauca. On

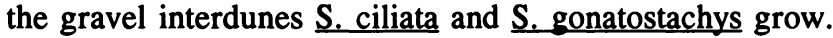

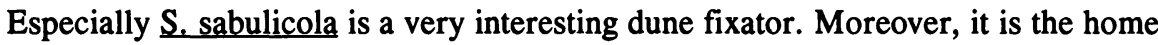
and source of food for a huge number of insects (moths, ants, scale insects, beetles,...).

Another conspicuous dune inhabitant is the succulent Trianthema hereroensis (Aizoaceae).

\subsubsection{The !Nara}

The most interesting dune plant, however, is Acanthosicyos horrida, a Cucurbitacean endemic to the Namib.

It was Friedrich Welwitsch who first described A. horrida. The !nara, as it is called locally, germinates on the wet sand after a heavy rain and then tries to reach the ground water level with its long tap root. Therefore it is not a 'true' desert plant as it has to remain in close contact with underground water sources.

It is a dioecious xerophytic plant (meaning that there are female and male plants: both sexes are separated; moreover these plants can tolerate heavy drought stress). Its numerous, robust terete (i.e. smooth and rounded) pale yellow to greyish-green photosynthesizing spiny stems have small leaves. These much-branched stems form large dense bushes. From these, only the young growing tips are sometimes eaten 
by animals. The stomata are arranged in longitudinal grooves where they are protected against desicative winds (Van Damme, 1990). The spines are paired, opposite, sharp and straight. The flowers are up to $12 \mathrm{~mm}$ long, pale yellow or greenish, standing solitary in the axils of the very small leaves. The fruit is initially light green, becoming pale orange-yellow when ripe.

According to archaeological evidence $\underline{A}$. horrida has been a staple food in the central Namib desert for over 8000 years (Sandelowsky, 1977). Locally, the !nara is still used and traded on a small scale. Its fruits are covered with blunt protuberances and have a jelly-like flesh in which flat, creamy white seeds are embedded. Each year many Topnaar make expeditions to harvest the !nara melon. It is a time-consuming and arduous task. Each fruit is prodded for ripeness and then, well-protected as it is by the spiny stems, teased from the patch with a stick. After the harvest the sweet-tasting pulp, which has a strong herbal smell, is removed and boiled over a fire. The seeds are strained from the soup and the cooked !nara is poured onto clean sand. After two or three days the pancake is turned so that the oil from the other side can drain away. When dry, it is cut into strips and taken to the village where it is stored. It is eaten as a sweet which is placed against the palate and licked rather than chewed because of the sand adhering to it.

The seeds are dried in the sun and sold. They cannot be kept too long because they become rancid after a certain time. These 'butterpits', as they are called in southern Africa, can be eaten as such, are used in baking and as a rennet substitute. As such, the seed is also an essential part of the Topnaars' diet. The fruit pulp and the plant sap contain an enzyme which curdles milk. It is not volatile and is destroyed by heat like most other enzymes. Elaterase has also been isolated from the juice of the young bitter and ripe non-bitter fruit (for further details consult Watt \& BreyerBrandwijk, 1962).

\subsection{Rocky Ridges with Crevices}

In arid areas, accumulations of erosive material under rocks and rock crevices are favourable sites for the development of plants. Run-off water can collect there and thus provide adequate moisture so that even non-xerophytic plants can grow and develop there for a limited period or over longer stretches of time.

According to Walter (1986), ridges of quartzite, dolerite and marble are biotopes preferred by succulents. In the Namib, typical succulents are: Hoodia currori, Trichocaulon clavatum (syn. T. dinteri), T. sociarum and T. pedicellatum 
(Asclepiadaceae) and Lithops ruschiorum (Aizoaceae). These are mostly small succulents.

The same author adds a number of other plant types growing in these biotopes. They comprise stenohydrous xerophytes (for definition see infra), such as Kleinia longiflora, Othonna protecta (Asteraceae), Pelargonium otaviense, Sarcocaulon

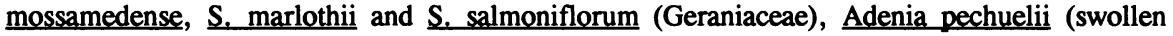
tuberous stem; Passifloraceae).

The genus Sarcocaulon comprises 14 species which are all confined to southern Africa. Stems and branches are covered with a fairly hard, translucent bark which is inflammable because it is impregnated by wax. Once the stem material has withered away the hollow bark can be used as a candle. Local vernacular names

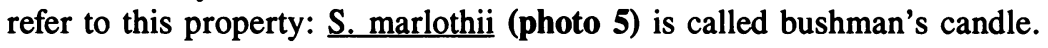

Larger succulents are also present: Cotyledon orbiculata (an evergreen succulent with upright cylindrical leaves, growing on rocky slopes; Crassulaceae), Euphorbia gariepina, E. damarana (photo 6), E. lignosa and (the large candelabrum) E. virosa (Euphorbiaceae) and the prostrate Aloe asperifolia (Aloeaceae).

Occasionally some halophytes appear after a rain: Arthraerua spp. (Amaranthaceae), Salsola spp. (Chenopodiaceae), Sesuvium sesuvioides (Aizoaceae) and Zygophyllum stapfii (Zygophyllaceae).

Arthraerua leubnitziae, the pencil plant, is endemic to Namibia and found nowhere else in the world. It forms low dark green bushes that trap wind-blown sand to form hummocks. It grows in the fog belt. It cannot absorb fog directly, but utilizes the water that accumulates on the soil's surface. The erect stems are jointed, thick and juicy and $50 \mathrm{~cm}$ long. Leaves are reduced to scales. Stems contain chlorophyll and photosynthesize. Stomata are sunken into longitudinal grooves that are visible on the stem much as in Euphorbia tirucalli (the pencil tree; Van Damme, 1989).

Salsola plants appear old and weathered because of all the apparently dry dead wood around them (photo 7). Under favourable conditions, however, these seemingly dry stems may sprout and produce small, scale-like leaves that are arranged close on the branches. Because of their salt content some species are relished by browsing animals (Craven \& Marais, 1986). Zygophyllum stapfii is endemic to the Namib.

After a rain, various herbaceous species appear.

Among these we mention Acanthopsis spp., Monechma arenicola, Petalidium spp. (Craven, unpublished data, lists 10 different species) and Blepharis spp. (all Acanthaceae; Blepharis comprises B. gigantea, B. grossa, B. mitrata and B. obmitrata, fide Craven, unpublished data), Gazania jurineifolia and Helichrysum roseo-niveum (Asteraceae) and Sutera maxii (Scrophulariaceae). 
Most of these require unusually good rains before their seeds germinate (e.g. Blepharis grossa, Petalidium pilosi-bracteolatum and P. variabile; Craven \& Marais, 1986).

Helichrysum roseo-niveum is well-protected from excess heat through its whitewoolly hairs covering the leaves. Commonly called the South West Edelweiss it can be used as mattress stuffing. Sutera maxii leaves are also covered with soft, short hairs which are sticky and often wet to the touch.

To these species Von Willert et al. (1984 and 1985) add Othonna opima (an evergreen plant with upright succulent cylindrical leaves, growing exclusively on rocky slopes; Asteraceae), Stoeberia beetzii var. arborescens (an evergreen shrub with cylindrical leaves, growing on rocky slopes; Aizoaceae), Ozoroa dispar (a tree with deciduous sclerophyllous leaves, only growing on rocks; Anacardiaceae), Monechma mollissimum (a herbaceous shrub; Acanthaceae) and Zygophyllum longicapsulare (a prostrate shrublet belonging to the Zygophyllaceae).

\subsection{Large Grasslands of the Inner Namib}

The inner Namib has no fog. The vegetation therefore solely depends on summer rains which are too irregular to allow any farming.

A sandy debris overlies the rocks of the platform. When it rains grasses grow on the debris. Whenever the ground is stony the grassland is replaced by a zone of Euphorbia gregaria (Euphorbiaceae). Further west, where it is drier, Euphorbia is restricted to rivulets and Aloe asperifolia appears on the plains. Still further to the west, the gravel desert of the outer Namib is without any vegetation.

All the Poaceae of the inner Namib belong to the perennial genus Stipagrostis. $\underline{S}$. obtusa has the lowest water requirement. $\mathbf{S}$. ciliata, $\mathbf{S}$. hochstetterana and $\mathbf{S}$. uniplumis need more water (in ascending order). These species succeed to one another in the above sequence from west to east, with mixed stands between pure ones. They all are typical climax grasses for sandy stands; it are valuable and very palatable fodder grasses with a highly nutritive value even when dry.

Grasses have a superficial root system and consume all the available water leaving no water and space for other (dicotylous) herbs or shrubs. 


\subsection{The Welwitschia Biotopes}

Welwitschia mirabilis (photo 8, 9 and 10) is the only member of the Welwitschiaceae family which belongs to the Gnetopsida, a very primitive taxonomic plant group. It is a real curiosity in context and a true botanist's delight in a great number of respects.

The plants typically grow in riviere beds and in their valleys, thus indicating the presence of sometimes limited amounts of available water in the subsoil. Only in more humid regions the plants occur on plains or slopes. Walter (1986) mentions that the roots do not reach the water table. It should be added that it avoids riviere with strong flood currents, probably because its seedlings cannot survive when covered with sand.

It still is a point of dispute whether fog is a water source for Welwitschia or not (Bornman, 1978; Von Willert et al., 1985). Recently, there has been a tendency to say it is not because:

(1) fogs rarely reach the inner Namib;

(2) the leaves of Welwitschia lie too close to the soil and are therefore hardly able to condense fog;

(3) the scleromorphic bilateral leaves possess no structures enabling them to absorb water: the cuticle is thick and stomata, and stomatal apertures, are covered with a cutine layer (Walter, 1986).

Osmotic potential measurements of leaf cells indicate that theoretically water vapour uptake from saturated air cannot be completely excluded, but if it would occur it would hardly play an important role in the overall annual water balance of the plant.

Water losses are limited through a number of mechanisms. The two large leaves

(1) reflect incoming radiation and further reduce heat build up through

(2) convective heat loss partly at the underside of the leaves towards the self-shaded (and thus somewhat cooler) soil surface.

When drought stress becomes severe the leaves dry and die off starting from the tips which are in touch with the hot soil. They may die down to their basal 
meristems (i.e. the tissues at the basis of the leaves from which the leaves grow), reducing the transpiring surface to nearly zero. After a more humid period or a shower these meristems quickly start producing new leaf tissue.

Welwitschia seems to be the only gymnosperm species which has the enzyme system necessary for crassulacean acid metabolism (CAM) (Dittrich and Huber, 1974) and also contains the peripheral reticulum in the chloroplasts of its bundle sheets normally occurring in CAM and $\mathrm{C}_{4}$ plants (Whatley, 1975), but it is not clear at all whether Welwitschia actually uses this CAM strategy in order to avoid drought stress.

Schulze et al. (1976) affirm that Welwitschia is a true CAM plant. Bornman (1978) states that Welwitschia adopts a CAM strategy when growing in true desert (sic) conditions, whilst it follows $\mathrm{C}_{3}$ when growing in more tempered climatic conditions. These different biotopes' influences might explain why Von Willert et al. (1983a, b and c; 1984) state that Welwitschia is a true $C_{3}$ plant (they could not evidence nightly carbon dioxide uptake: Von Willert et al., 1982) while Wagner \& Larcher (1981) maintain that CAM in Welwitschia mirabilis can appear as a result of alternating high day and low night temperatures which would make it a facultative CAM plant (sensu Osmond, 1978). Ting \& Burk (1983) and Winter \& Schramm (1986) may be right in concluding that Welwitschia is a CAM cycler, which means that $\mathrm{CO}_{2}$ is taken up during the light phase (like in any $\mathrm{C}_{3}$ or $\mathrm{C}_{4}$ plant) in combination with an evident diurnal acid fluctuation (which is a typical CAM feature).

The mature seed is winged. It is airborne for only short distances. Exceptionally it can be blown over larger distances, away from the mother plant. Most remain in the vicinity of the parent, however. There they will find the most appropriate germination and growing environment. Seeds contain a germination inhibitor which has to be washed out by a rain of minimally $25 \mathrm{~mm}$ before germination can take place. This dormancy mechanism limits germination to exceptionally good rain years and thus guarantees seedling survival.

The number of viable seeds is strongly reduced because of an Aspergillus niger infection which is (in)directly promoted by the punctures made by a large, winged pyrrhocorid bug (Probergrothius sexpunctatis) which completes its life cycle on Welwitschia mirabilis.

Welwitschia is a dioecious plant. The reproductive structures are borne on cones that are attached to stalks originating from the meristematic stem tissue. The male reproductive structure (photo 9) is closely related to the true flower found in 
angiosperms. It consists of six trilocular anthers enclosed by a perianth formed from two bract-like structures. In the centre there is an aborted pistil the ovary of which contains a single sterile ovule. The female reproductive structure (photo 10) is not a true flower: a single naked ovule is borne on a subtending bract or cone scale. The scales are arranged oppositely and decussately on a cone which resembles that of a pine both in shape and size. The ovule is not enclosed within an ovary so that this female "flower" closely resembles the reproductive system found in the gymnosperms.

\subsection{Domed Inselbergs}

The precipitation in these areas is higher than in the outer Namib. Not only there is more rainfall but they also intercept more fog. Therefore, the flora and vegetation are richer (in spite of the less frequent fogs due to their inland position). An interesting case study is presented by Robinson (1977) who gives a list of 118 species of angiosperms for the granite surroundings of Mirabib (north of Kuiseb river).

The list of species given here is inspired by Walter (1986) and Seely (1987).

Commonly found are the shrubby Acacia erioloba and Parkinsonia africana (Leguminosae), Boscia spp. (Capparidaceae; species include B. albitrunca, B. foetida and B. rautanenii, fide Craven, unpublished data and Seely, 1987), Rhus marlothii (Anacardiaceae), Commiphora spp. (esp. C. saxicola; Burseraceae; Craven, unpublished data, lists 16 different species), Montinia caryophyllacea (Grossulariaceae), Moringa ovalifolia (a trunk water storing tree, with horseradish-like roots and edible fruits and leaves; Moringaceae) and Lycium spp (L. cinereum, $\underline{L}$. decumbens and $\mathrm{L}$. eenii, fide Craven, unpublished data; Solanaceae). All of these are typical desert trees with wide distributions and occurring in other arid areas as well.

Parkinsonia africana is the only species of this genus naturally found in southern Africa. The Mexican species, P. aculeata (the Jerusalem thorn) is widely cultivated and has become naturalized in parts. The numerous branches of $\underline{P}$. africana are smooth and the young ones are armed with horizontal spines that are modified lateral shoots which may bear leaves and flowers. The trees are usually leafless; when leaves are present they are reduced to a midrib; leaflets are minute, inconspicuous and scale-like. The trees are browsed by animals and the seeds are said to make an excellent coffee. Leaves have been used as a medicine by inhabitants of the Namib (Craven, 1986).

Boscia albitrunca (caper bush or shepherd's tree) yields an edible fruit. The root is used for food and preparation of drinks (the roasted, ground root is a substitute 
for coffee or chicory) and porridge. The hollow trunks form natural reservoirs for rainwater. The pickled flower buds are said to be as good as European capers (made from Capparis spinosa) (Fox \& Young, 1982).

B. foetida offers in globo the same possibilities. A number of Commiphora spp. yield edible fruits. $\mathbf{C}$. pyracanthoides is known as the water plant because it has a sappy underground tuber (Fox \& Young, 1982). The fruits of Lycium decumbens can be eaten raw when fresh.

Dwarf shrubs are also present. Conspicuous genera comprise Adenolobus (Leguminosae), Dyerophytum (Plumbaginaceae) and Sarcocaulon (Geraniaceae).

There are also many grasses and herbs like $\underline{S t i p a g r o s t i s ~ c i l i a t a ~ a n d ~} \underline{S}$. hochstetterana (Poaceae) and the large succulent Euphorbia virosa (Euphorbiaceae). Aloe dichotoma (Aloeaceae) grows in the inner Namib on slopes of mica schist (the medicinal properties of the Aloe spp. have been reviewed by Bruce, 1975).

Between the monarocks there are riviere carrying fresh water and allowing Acacia erioloba, Boscia spp. and Commiphora pyracanthoides to grow together with many herbs and grasses which are absent from the outer Namib.

\section{Physiological Considerations}

In what follows, we will briefly discuss a number of physiological adaptations that some of the plants that occur in the Namib desert have developed to survive the harsh conditions to which they are exposed. For more ample information about adaptations to drought stress in general, the reader is referred to Van Damme $(1990,1991 \mathrm{a}, \mathrm{b}, \mathrm{c}$ and $\mathrm{d})$.

\subsection{Resurrection Plants}

Resurrection plants (sensu Gaff, 1977: desiccation tolerant plants) can be found on rocky surfaces and shallow soils. In conditions as these, drought avoidance mechanisms are periodically likely to fail to protect the plant from intense drought stress, consequently, selection for increased drought tolerance becomes a potent factor.

Colonisation of depressions in granite rocks may commence with a number of Scrophulariaceae (e.g. Chamaegigas intrepidus, a hydrophytic xerophyte) which have desiccation tolerant leaves. They are followed by various taller resurrection 
species and eventually by species whose drought resistance depends on avoidance mechanisms, e.g. Aloe spp.

A resurrection plant that only occurs in southern Africa is Myrothamnus flabellifolius. It is typical for the granite kopjes of the region and has been found in several locations in the Namib desert (Puff, 1978). Its strong smell and taste make it an interesting plant for teas. The leaves are also stated to contain a balsam: dried together with the stems they can be rolled up and smoked to relieve asthma.

Many resurrection species are confined to these shallow, dry soil environments, a few are found on deeper soils as well (e.g. Eragrostis nindensis, the eight-day grass).

\subsection{Ephemerals}

Ephemerals or short-lived plants also occur in the Namib. They avoid drought stress by completing their life cycle (or at least the reproductive phase) during the sometimes short rainy season. They then live off run-off water that gathers in shallow spots (Mooney, 1980). Seeds carry them through the subsequent dry period, which can last several years.

In the Namib, many of these ephemerals are grasses (esp. of the genus Stipagrostis). Their seeds can withstand exposure to high temperatures, whereas the plants would simply wither and die in the same conditions. The seeds can lie dormant for several years. They only germinate with the advent of favourable conditions.

\subsection{Survival by Partial Death}

Stenohydrous xerophytes are an important ecological group in the Namib desert (Walter, 1986). They survive protracted droughts by shedding their transpiring organs with increasing drought stress.

In most cases, the plants shed their leaves. In a number of instances, however, stems are also thrown off: Zygophyllum dumosum sheds its leaflets early in the dry period while the green succulent transpiring petioles persist or are partly shed later in summer (Schulze et al., 1972).

Through this process of 'survival by partial death' (Evenari et al., 1976) or 'partial drought evasion' (Orshan \& Geula Zand, 1962) plants can start growing from the remaining material when conditions get better. 


\section{CAM: A SPECIAL FORM OF PHOTOSYNTHESIS TO AVOID EVAPOTRANSPIRATION}

Plants need to take up carbon dioxide $\left(\mathrm{CO}_{2}\right)$ in order to grow. In combination with water (which is taken up by the roots) and using solar energy (light), the green plant parts produce sugars and oxygen. This process is known as photosynthesis.

In most cases, plants take up $\mathrm{CO}_{2}$ through their open stomata during the day when there is light. The $\mathrm{CO}_{2}$ that is taken up is primarily converted in a chemical compound consisting of three carbon atoms in $\mathrm{C}_{3}$ plants. In $\mathrm{C}_{4}$ plants this first metabolic product is a chemical made up of four carbon atoms.

There is, however, a third possibility. In order to avoid evapotranspiration through the open stomata, plants can open their stomata only at night to take up the $\mathrm{CO}_{2}$. It is then stored within the plant (in the form of an acid) and the next day converted into sugar, using light energy like the plants discussed above. The system whereby $\mathrm{CO}_{2}$ is taken up nightly is called Crassulacean Acid Metabolism (CAM) because it was first evidenced in the Crassulacean family and because an important intermediate chemical of this metabolic system is an acid. To be complete, it should be added that most CAM plants can also take up $\mathrm{CO}_{2}$ during the light phase; this is, however, mostly confined to those periods of the year whereby growing conditions are optimal (i.e. during the rainy season).

CAM plants especially occur in dry areas while $C_{3}$ plants are more typical for temperate zones. 
When plants shed their leaves, their remaining parts can remain photosynthetically active. These plants are then called aridoactive plants. When no photosynthesis takes place they remain "aridopassive". The former are in most cases CAM-plants.

\subsection{Crassulacean Acid Metabolism}

The vegetation of the subtropical arid zone of southern Africa, mainly in the area of the Namib desert south of the Orange river (Richtersveld) is undoubtedly richer in CAM exhibiting succulents than any other dry habitat. The dominance of CAM plants there results from its climatic features: rain in the winter season, usually cool and humid nights and frequently occurring fog or dew fall.

The CAM-syndrome consists of a number of typical adaptations enabling plants to survive very dry conditions for long periods.

Families in which CAM has been described and which occur in the Namib are: Welwitschiaceae, Liliaceae, Aizoaceae, Asclepiadaceae, Euphorbiaceae, Portulacaceae, Vitaceae, Asteraceae, Chenopodiaceae, Crassulaceae and Convolvulaceae (Smith, 1982). Szarek \& Ting (1977) add Cucurbitaceae and Geraniaceae to this list.

\subsubsection{CAM and Succulents}

(plant species listed in this paragraph are based on Von Willert et al., 1985, and Walter, 1986)

CAM is present in the many succulents that grow in the Namib. These plants have a well-developed root system that can take up large amounts of water after a rain, and this water is then stored in the hydrenchyma (water storing tissue) and chlorenchyma (photosynthetic-active tissue) and used sparingly during the dry period.

The Namib has many

- leaf succulents:

Aloe asperifolia, Aloeaceae; Crassula brevifolia and C. deceptrix, together with Cotyledon orbiculata, Crassulaceae; Cheiridopsis spp., evergreen leaf succulents of about $10 \mathrm{~cm}$ height, belonging to the Aizoaceae, 
- stem succulents:

Euphorbia virosa and E. damarana, Euphorbiaceae; Hoodia spp. and Trichocaulon spp., Asclepiadaceae; Senecio longiflorus, Asteraceae

- and leaf and stem succulents:

Aloe dichotoma; Brownanthus schlichtianus, an Aizoacean with an evergreen stem and deciduous, CAM-exhibiting leaves; further Aizoaceae include: Psilocaulon subnodosum, several Ruschia spp., including $\underline{R}$. schneideriana, Sphalmanthus trichotomus and Stoeberia beetzii which are all succulent shrubs with evergreen leaves; Tylecodon reticulatus, Crassulaceae.

Some of these succulents develop into small trees. Ceraria namaquensis (Portulacaceae) is a small tree with seasonally deciduous, tiny succulent leaves. Because of their well-developed cuticle their cuticular transpiration is extremely low.

The extremely succulent Aizoaceae genera, like Aizoanthemum, Aizoon, Drosanthemum, Hereroa, Lithops and Ruschia (Walter, 1986) have a high chloride percentage in their cell sap. They represent therefore a transition to the succulent halophytes, but in contrast to them also grow well on salt-free soils.

\subsubsection{Switches Between CAM and $C_{3}$}

It should also be mentioned that a number of these succulents switch from $\mathrm{C}_{3}$ to CAM when conditions get too dry or salty. The change from $\mathrm{C}_{3}$ to $\mathrm{CAM}$ leads to an increase in the water use efficiency (i.e. that less water is used for a similar biomass production) and is reversible. This system has been called facultative CAM (Osmond, 1978) as opposed to obligate CAM (plants following CAM in all conditions) although a number of authors (i.e. Deléens \& Queiroz, 1984) do not agree on this subdivision.

Field investigations indicate that this change represents an ecological adaptation to conditions of reduced water availability. Plants germinating during the rainy season show characteristics of $\mathrm{C}_{3}$ photosynthesis for the first 3 months of their life cycle. Later on, at the onset of the dry season, pronounced CAM develops.

These phenomena have been studied extensively with Mesembryanthemum crystallinum (Winter \& Lüttge, 1979; Stuve \& Lüttge, 1988) and are also valid for Mesembryanthemum guerichianum (photo 4) which can be found throughout the Namib (with a greater incidence in the southern part, where it also is noticeably more succulent (sic; Craven \& Marais, 1986) usually in river beds and disturbed areas where moisture has collected. This fleshy annual has the typical crystal clear 
glistening papillae (i.e. small nipple-like protuberances, having a fleshy aspect, on a plant's surface) found on a number of Mesembryanthemum spp.

A number of Euphorbia spp. and Pachypodium spp. (Apocynaceae) occurring in the Namib combine CAM-stems with $\mathrm{C}_{3}$ leaves. These leaves are shortlived and only occur during periods of stem growth when ecological conditions are favourable (Van Damme, 1989). Plants displaying this combination have a competitive advantage over plants only taking up $\mathrm{CO}_{2}$ through $\mathrm{CAM}$ or $\mathrm{C}_{3}$. CAM plants normally are slow-growing and have low productivity, whilst $\mathbf{C}_{3}$ plants are usually shortlived and less drought tolerant.

When conditions get extremely dry, nightly $\mathrm{CO}_{2}$ uptake through $\mathrm{CAM}$ also stops. The internal diurnal acid cycle, however, in most cases continues. This maintains low internal osmotic potentials so that when water becomes available again with the first rains it can immediately be taken up. Moreover, through this idling process metabolism continuous so that in a number of cases plants can still increase in dry weight even in the driest conditions.

One could expect that CAM plants in the Namibian desert would show this CAM idling with increasing drought stress. Von Willert et al. (1983b and 1985), however, were unable to prove that the acid cycle was indeed maintained in plants that survive in extreme dry conditions (species included several Aizoaceae:

Brownanthus schlichtianum, Cheiridopsis spp. Psilocaulon subnodosum, Ruschia schneideriana, Sphalmanthus trichotomus and Stoeberia beetzii; Crassulaceae: Tylecodon reticulatus, Crassula

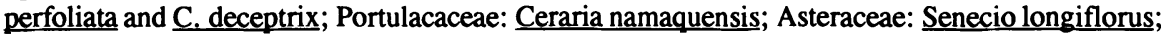
and Liliaceae: Aloe pearsonii).

\subsection{Thorns}

A striking feature of the Namib plants is their lack of thorns, although there are, of course, a few exceptions like Acanthosicyos horrida, Hoodia spp. and Sarcocaulon spp. By contrast, more than half of all perennial succulents, shrubs and trees of the American deserts produce thorns (Leopold, 1961, cited by Bornman, 1978).

Thorniness is important as it protects plants against browsers (Ehleringer, 1980). That there are only a few thorny species in the Namib would therefore indicate that browser load on the perennial vegetation is minimal to negligible: when it rains, shortlived grasses provide abundant food for such species as springbuck and zebra while during drought periods these animals migrate. It should be added that thorns 
have an influence on light interception and can lower tissue temperature through the shadow they produce (Nobel, 1983).

\section{Conclusion}

From the above it is clear that the Namib can be divided in a few ecologically interesting zones which all have a specific flora. Numerous plant species have properties that make them interesting for man because they can be eaten or used otherwise, or because they can be used in breeding programmes aimed at improving existing crop plants.

The endemics, i.e. plants that are only found in the Namib desert, add an interesting feature because they can give some clues about how plants have adapted to the extreme dry conditions of the Namib.

Moreover, it should be clear that the Namib desert flora is something of a meeting point for scientists coming from different disciplines: botanists, agronomists, sociologists, anthropologists and archaeologists can all contribute to a more thorough knowledge of this thrilling environment

Acknowledgements The author is greatly indebted to the European Community for financial support. He also wishes to thank prof. H. Dumont and prof. D. Beke for constructive criticism on the draft text.

\section{REFERENCES}

Besler, H. 1972. Klimaverhältnisse und klimageomorphologische Zonierung der zentrale Namib (Südwestafrika). Stuttgarter Geographische Studien, 83, 1 -209. University of Stuttgart, Stuttgart.

Besler, H. 1980. Die Dünen Namib: Entstehung und Dynamik eines Ergs. Stuttgarter Geographische Studien, 96, 208 pp.

Besler, H. \& Marker, M.E. 1979. Namib sandstone: a distinct lithological unit. Transactions of the Geological Society of South Africa, $\underline{82}, 155-160$.

Bornman, C.H. 1978. Welwitschia, paradox of a parched paradise. Struik, Cape Town, 71 pp.

Boyer, D.C. \& Boyer, H.J. 1989. The status of alien invasive plants in the major rivers of the Namib Naukluft Park. Madoqua, 16 (1), 51 - 58. 
Bruce, W.G.G. 1975. Medicinal properties in the Aloe. Excelsa, 5, 57 - 68.

Craven, P. \& Marais, C. 1986. Namib flora. Swakopmund to the giant Welwitschia via Goanikontes. Gamsberg, Cape Town, 128 pp.

Deléens, E. \& Queiroz, O. 1984. Effects of photoperiod and ageing on the carbon isotope composition of Bryophyllum daigremontianum Berger. Plant. Cell and Environment, 7, 279 283.

Dittrich, P. \& Huber, W. 1974. Carbon dioxide metabolism in members of the Chlamydospermae. In: Proceedings of the 3rd International Congress of Photosynthesis, 1573 1578. Elsevier, Amsterdam.

Doidge, E.M. 1946. The South African fungi and lichens. Bothalia, 5, 225 - 376.

Dumont, H.J. 1987. Why are there no aquatic turtles in the relict waters of the Sahara? Journal of arid environments, $12,151-158$.

Ehleringer, J. 1980. Leaf morphology and reflectance in relation to water and temperature stress. In: Turner, N.C. \& Kramer, P.J. Adaptation of plants to water and high temperature stress, 293 - 308. Wiley, New York.

Evenari, M., Schulze, E.-D., Lange, O.L., Kappen, L. \& Buschbom, U. 1976. Ecological studies 19: 439 - 451. Springer Verlag, Berlin.

Fox, F.W. \& Young, M.E.N. 1982. Food from the veld. Delta, Craighall.

Gaff, D.F. 1977. Desiccation tolerant vascular plants of southern Africa. Oecologia, 31, 95 109.

Giess, W. 1981. Die in der Zentralen Namib von Südwestafrika/Namibia festgestellten Pflanzenarten und ihre Biotope. Dinteria, 15, 13 - 69.

Jacobsen, N.H.G. \& Moss, H. 1987. A contribution to the flora of the Northern Namib. Dinteria, 19, 27 - 68.

Knetsch, G. 1960. Ueber aride Verwitterung unter besonderer Berücksichtigung natürlicher und künstlicher Wände in Aegypten. Zeitschrift Geomorphologie, 1 .

Lancaster, N. \& Ollier, C.D. 1983. Sources of sand for the Namib sand sea. Zeitschrift Geomorphologie, 45 (suppl.), 71 - 83.

Logan, R.F. 1960. The Central Namib Desert, South West Africa. National Academy of Sciences, National Research Council, publication 758, 162 pp. 
Logan, R.F. 1969. Geography of Central Namib Desert. In: McGinnies, W.G. and Goldman, B.J., Arid lands in perspective, 128 - 143. University of Arizona Press, Tucson.

Martin, H. 1964. A suggested theory for the origin and a brief description of some gypsum deposits of South West Africa. Transactions of the Geological Society of South Africa, 67.

Martin, H. 1965. The precambrian geology of South West Africa and Namaqualand. The precambrian research unit, University of Cape Town, Cape Town.

Mattick, F. 1970. Flechtenbestände der Neblewüste und Wanderflechten der Namib. Namib Meer (Swakopmund), 1, 35 - 44.

Müller, M.A.N. 1985. Gräser Südwestafrika/Namibias. Windhoek, Forestry Department, 286 pp.

Nobel, P. 1983. Spine influences on PAR interception, stem temperature, and nocturnal acid accumulation by cacti. Plant, Cell and Environment, 6 , $153-159$.

Orshan, G. \& Geula Zand 1962. Seasonal body reduction of certain desert halfshrubs. The bulletin of the research council of Israel, 11D (1), $35-42$.

Osmond, C.B. 1978. Crassulacean acid metabolism: a curiosity in context. Annual Review of Plant Physiology, 29, 379 - 414.

Puff, C. 1978. Zur Biologie von Myrothamnus flabellifolius Welw. (Myrothamnaceae). Dinteria, $14,1-20$.

Robinson, E.R. 1977. List of plant species from the Mirabib hill area. Madoqua, 10 (4), 295 297.

Sandelowsky, B. 1977. Mirabib - an archaeological study in the Namib. Madoqua, 10 (4), pp $221-283$.

Schulze, E.-D., Lange, O.L., Buschbom, U., Kappen, L. \& Evenari, M. 1972. Stomatal responses to changes in humidity in plants growing in the desert. Planta, 108, $259-270$.

Schulze, E.-D., Ziegler, H. \& Stichler, W. 1976. Environmental control of Crassulacean Acid Metabolism in Welwitschia mirabilis Hook. fil. in its range of natural distribution in the Namib desert. Oecologia, 24, 323 - 334.

Seely, M. 1987. The Namib. Windhoek, Shell, $104 \mathrm{pp}$.

Smith, B.N. 1982. General characteristics of terrestrial plants (Agronomic and Forests) - $C_{3}, C_{4}$ and crassulacean acid metabolism plants. CRC Handbook of Biosolar Resources, 1 (2), 99 - 113. Cleveland, Ohio. 
Struve, I. \& Lüttge, U. 1987. Characteristics of MgATP ${ }^{2-d}$ ependent electrogenic proton transport in tonoplast vesicles of the facultative crassulacean-acid-metabolism plant Mesembryanthemum crystallinum L. Planta, 170, 111 - 120.

Struve, I. \& Lüttge, U. 1988. Biochemical and immunological properties of solubilized tonoplast ATPase of the facultative CAM plant Mesembryanthemum crystallinum in the $\mathrm{C}_{3}$ and CAM states. Botanica Acta, 101, 39 - 44.

Szarek, S.R. \& Ting, I.P. 1977. The occurrence of Crassulacean Acid Metabolism among plants. Photosynthetica, $11(3), 330$ - 342.

Ting, I.P. \& Burk, J.H. 1983. Aspects of carbon metabolism in Welwitschia. Plant Science Letters, $\underline{32}, 279-285$.

Van Damme, P. 1989. Euphorbia tirucalli: morphology, physiology and cropping conditions, Doctoral thesis, 375 pp. State University Ghent, Belgium.

Van Damme, P. 1990. Adaptations to drought stress in plants. Part I. Typology of drought tolerance and resistance. Mededelingen van de Faculteit van de Landbouwwetenschappen, 55 (1), $121-126$.

Van Damme, P. 1991a. Adaptations to drought stress in plants. Part II. Morphological adaptations. Mededelingen van de Faculteit van de Landbouwwetenschappen, $\underline{56}$ (1), 1 - 8.

Van Damme, P. 1991b. Adaptations to drought stress in plants. Part III. Anatomical adaptations. Mededelingen van de Faculteit van de Landbouwwetenschappen, 56 (1), 9 - 13.

Van Damme, P. 1991c. Adaptations to drought stress in plants. Part IV. Physiological adaptations at stomatal level. Mededelingen van de Faculteit van de Landbouwwetenschappen, $\underline{56}(1), 15-20$.

Van Damme, P. 1991d. Wijs met water. Droogte-aanpassingen bij planten. Natuur en Techniek, 59, $460-471$.

Von Willert, D.J., Eller, B.M., Brinckmann, E. \& Baasch, R. 1982. $\mathrm{CO}_{2}$-gas exchange and transpiration of Welwitschia mirabilis Hook fil. in the Namib Desert. Oecologia, 55, 21 - 29.

Von Willert, D.J., Brinckmann, E., Eller, B.M. \& Scheitler, B. 1983a. $\mathrm{CO}_{2}$ exchange of CAM exhibiting succulents in the southern Namib desert in relation to microclimate and water stress. Photosynthesis Research, 4, 289 - 298.

Von Willert, D.J., Brinckmann, E., Scheitler, B. \& Eller, B.M. 1983b. Responses of Crassulacean acid metabolism (CAM) to increasing and decreasing water stress in plants in the southern Namib desert. In: Advances in agricultural production. Effects of stress on photosynthesis., 155 - 163. Martinus Nijhoff, Den Haag. 
Von Willert, D.J., Brinckmann, E., Baasch, R. \& Eller, B.M. 1983c. Welwitschia mirabilis Hook. Fil. - A CAM plant ? Ecophysiological investigations in the central Namib desert. In: Advances in agricultural production. Effects of stress on photosynthesis., 185 - 191. Martinus Nijhoff, Den Haag.

Von Willert, D.J., Brinckmann, E., Eller, B.M. \& Scheitler, B. 1984. Water loss and malate fluctuations during the day for plants in the southern Namib desert. Oecologia, 61, 393 - 397.

Von Willert, D.J., Brinckmann, E., Scheitler, B. \& Eller, B.M. 1985. Availability of water controls Crassulacean acid metabolism in succulents of the Richtersveld (Namib desert, South Africa). Planta, 164, 44 - 55.

Wagner, J. \& Larcher, W. 1981. Dependence of $\mathrm{CO}_{2}$ gas exchange and acid metabolism of the alpine CAM plant Sempervivum montanum on temperature and light. Oecologia, $\underline{50}, 88$ - 93.

Walter, H. 1986. The Namib desert. In: Ecosystems of the World, 12B, pp 245 - 282. Elsevier, Amsterdam.

Watt, J.M. \& Breyer-Brandwijk, M.G. (1962). The medicinal and poisonous plants of southern and eastern Africa. Livingstone, Edinburgh, 415 - 417.

Whatley, J.M. 1975. The occurrence of a peripheral reticulum in plastids of the gymnosperm Welwitschia mirabilis. New Phytologist, 74, 215 - 220.

Winter, K. \& Lüttge, U. 1979. C C $_{3}$-Photosynthese und Crassulaceen-Säurestoffwechsel bei Mesembryanthemum crystallinum L. Berichte Deutschen Botanischen Gesellschaft, 92, 117 132.

Winter, K. \& Schramm, M.J. 1986. Analysis of stomatal and nonstomatal components in the environmental control of $\mathrm{CO}_{2}$ exchange in leaves of Welwitschia mirabilis. Plant physiology, $\underline{82}$, $173-178$. 